\title{
Implementation of Discussion-Presentation Method of Flipped Classroom-Based Through Lesson Study
}

\author{
Yuli Ifana Sari*, Siti Halimatus Sakdiyah \\ Universitas PGRI Kanjuruhan Malang \\ Malang, Indonesia \\ *ifana@unikama.ac.id
}

\begin{abstract}
The aim of this study is to find out the use of discussion-presentation method of the flipped classroom-based through lesson study to improve concept understanding and communication skills. This study was classroom action research (CAR) through Lesson Study (LS) that consist of six cycles, each cycle uses CAR steps which consist of four stages, namely (1) planning, (2) implementation, (3) observation, and (4) reflection and integrated with three stages of LS, namely (1) plan, (2) do, and (3) see. The results showed that the students' average understanding of the concept in cycles $I$ to VI experienced a significant development, namely $50,66,73,79,86$, and 91 . The average result of communication skills in cycle $I$ to VI respectively, namely $45,51,59,65,75$, and 90 . It can be concluded that the application of the discussion-presentation method based on flipped classroom through lesson study can improve students' conceptual understanding and communication skills.
\end{abstract}

Keywords-discussion-presentation method, flipped class, concept understanding, communication

\section{INTRODUCTION}

Class A of 2015 intake is one of the classes that has better performance compared to other classes (B, C, D, and E). High average academic Performance is one of the characteristics of this class. However, based on the results of observations in the previous semester, there were still several problems, including (1) lack of understanding of students 'concepts on the material being studied, (2) the lack of students' ability to critical analysis of presented material so that the PowerPoint content that presented by the presenter during the presentation activity is not the essential points of the material that should be delivered so that it seems only copying and pasting, and (3) the students' lack of communication ability, these can be seen during the presentation activity, the presenters only read the material on PowerPoint. It seems that they did not understand the material presented.

The first reflections show that the students' lack of understanding of concepts and lack of communication skills during learning were because of the method used by the lecturer. Most of the class using an expository approach in which lecturer transferring the knowledge, giving examples, and giving exercises in the form of quizzes and assignments.
Teaching process seems not to facilitate student's competence development through independent or guided knowledge seeking. This is in line with Suwardjono [1], which states, "Teaching learning conditions in higher education in Indonesia, in general, have not been able to change academic insight and behaviour significantly."

In Geography Education Study Program usually lecturers work alone in preparing and implementing the courses. Certain lecturers' creativity in teaching students does not affect other lecturers because there is no sharing among lecturers about the teaching learning process. Thus, Collaboration between lecturers when planning, implementing and evaluating learning is very important to improve the quality of teaching learning in the Geography Education Study Program. The lecturers' mind set in increasing collaboration needs to be increased so that lecturers are willing to share and open minded to teaching quality. The lesson study approach is an alternative to improve the lecturer mind set in enhancing the teaching learning process $[2,3]$.

Lesson Study is a lecturer development coaching program that is carried out within the Faculty of Education through collaborative and continuous learning studies based on the principles of collegiality and mutual learning to build learning communities. Through this program, it is expected to improve the professional competence of lecturers and improve student achievement. Therefore, lesson Study (LS) is an effective solution to overcome learning problems. This is happening because there are still some lecturers who do not understand or care about learning results, learning strategies, methods, and proper assessment methods [4-6]. There is an assumption that face-to-face learning once a week has carried out learning under the existing rules because the understanding of a good learning assessment measured by the number of face-to-face meetings in the class, not based on conduciveness and learning outcomes.

Lesson Study (LS) is a teaching learning quality improvement program which is done by lecturers collaboratively. Lesson Study is designed through several steps namely; planning the teaching learning process to achieve the goals, implementing the teaching learning process, observing the implementation, and doing reflection to discuss the process 
as material for the improvement on the next cycle $[7,8]$. The main focus of the implementation of Lesson Study is student activity in class, with the assumption that student activities are related to lecturer activities during class teaching $[9,10]$.

The changing paradigm in the education of the 21 st century requires a change in learning that emphasizes of mastery on four soft skills, namely critical, collaborative, creative and communicative for lecturers [5,11]. This new paradigm is needed especially in the implementation of the Indonesian National Qualifications Framework Curriculum (KKNI) that currently implied in Universitas Kanjuruhan Malang. Lecturers' mind set and action patterns in managing and implementing the teaching learning process require creative and innovative lecturers to improve the quality of educational services, especially teaching learning process. The learning process and results need to be planned, implemented, and evaluated in order to develop towards an optimal direction.

The learning process in higher education units is carried out in an interactive, inspiring, fun, challenging, and motivating way for students to participate actively and provides sufficient space for the initiative, creativity, and independence according to the talents, interests, and students' physical and psychological development. In accordance with the Strategic Plan of Kanjuruhan University Malang, learning is directed at improving education quality. Therefore, the Geography Education Study Program's implementation of learning should comply with national education standards and the community's expectations and needs, which continue to develop dynamically by empowering lecturers and academic staff.

Lesson Study innovations that will be implemented use the presentation method of flipped classroom-based [12,13]. The process starts with the assignment given by lecturer to the students so that the students learn the material actively. The materials are delivered via web media or lecturers' textbooks. Similarly, the assignment instructions /question exercises are delivered before the class begin. The material is used as discussion material when learning in class so that the learning process in the classroom is more focused on student problems in understanding the material.

Discussion is a learning method that exposes students to a problem [14], while the presentation is a method of expressing ideas, ideas, feelings in public by one or more presenters by including a paper script or not [15]. Concept understanding is an understanding of a material that is not only at the level of remembering the concept but also having to re-express it in another form without changing the meaning contained in the concept [16]. Concept understanding indicators cover six cognitive domains, referring to the revised Bloom's Taxonomy [5], namely remembering (C1), understanding (C2), applying (C3), analysing (C4), evaluating (C5), and creating (C6). Communication skills are part of the social skills necessary for life in society. Higher education institutions can be used as a miniature of society to educate students in practicing their communication skills with others. Several communication elements are sources, communicators, messages, channels, message recipients, and results [17].

Universitas Kanjuruhan Malang, as one of the higher education institutions, has a mission to organize multiculturalbased education and learning, to produce graduates who are competitive, creative, independent, tolerant, democratic, and religious. At this time, the Geography Education Study Program continues to improve itself by increasing the quantity and quality of learning facilities and infrastructure to create a conducive, professional, and a good quality of learning. Various factors determine the quality of education. One of them is the learning process. Teaching learning developed in Geography Education Study Program allows students to improve conceptual, communicative, and collaborative understanding. Based on background of the studies mentioned, the objectives of the study are: (1) to determine the increase in concept understanding through the discussion-presentation method of flipped classroom-based, and (2) to determine the improvement of communication skills through the discussionpresentation method of flipped classroom-based.

\section{METHODS}

This study was Classroom Action Research (CAR) through Lesson Study (LS) consisting of six cycles, each cycle using CAR steps consisting of four stages, namely (1) planning, (2) implementation, (3) observation, and (4) reflection and integrated with three steps of LS, namely (1) plan, (2) do, and (3) see. Researcher' presence was very necessary because they were action planners, data collectors, and reporters of research results. In addition, researcher also played a role as compilers of teaching materials (activity sheets), implementers of actions (teacher/ lecturers), and report the research results. Meanwhile, peer observers acted as observers during the learning process. The research subjects were class A student's class 2015 Geography Education Study Program, Faculty of Education, Universitas Kanjuruhan Malang in the odd semester of the 2017/2018 school year consisting of 41 students, 16 male students and 25 female students in the geography course's evaluation.

The instruments used include 1) LKM and individual assignments given one week before the material was delivered to measure students' conceptual understanding, 2) student communication skills rubrics, and 3) Observation sheets consisting of the implementation of lesson study and student response sheets to learning activities. Furthermore, the data analysis was carried out at the end of each cycle.

\section{FINDINGS AND DISCUSSION}

Based on the data analysis, the result show that the improvement of the students' concept understanding was $50,66,73,79,86$, and 91 while for communication skill were 45 , $51,59,65,75$, and 90 . The detail result can be seen in table 1 . 
TABLE I. IMPROVEMENT OF STUDENT UNDERSTANDING OF CONCEPTS AND COMMUNICATION SKILLS

\begin{tabular}{|l|l|l|}
\hline Actions in Cycle & Concept Understanding & Communication Skills \\
\hline I & 50 & 45 \\
\hline II & 66 & 51 \\
\hline III & 73 & 59 \\
\hline IV & 79 & 65 \\
\hline V & 86 & 75 \\
\hline VI & 91 & 90 \\
\hline
\end{tabular}

Lesson Study is one of the strategies for teacher and lecturer professional development. Lecturers develop learning collaboratively. One lecturer was assigned to handle the teaching process, and another lecturer observed the students' learning. This process is carried out during the learning process. At the end of the activity, the lecturer opened the question and answer session about the lesson, revised, and planned the next lesson based on the discussion results.

Lesson Study is different from other professional development management, it needs continuity and comprehensive professional development process. This case allowed lecturers to explore the real challenges in learning in the classroom. "Lesson Studies help define strategies, best practices and build capacity because they encourage relationships and collaboration with colleagues" [18]. Moreover, Lesson Study is carried out repeatedly for a long time because every learning process is not always the same and there is no perfect learning process so that the cycle will keep repeating itself [19].

The first step in Classroom Action Research (CAR) through Lesson Study (LS) was observation. This observation aimed to find the class' main problems that will be the object of research. Based on the problems found during observation, a solution to these problems is sought. There are two types of learning methods selected in the study, there are discussions and presentations on flipped classroom-based [6]. The discussion-presentation method is a learning method that has the purpose of expressing ideas, concepts, or problems in public. Then these ideas are discussed and solved by the students in the class to answer the questions, add and understand knowledge, and decide a decision. Meanwhile, a flipped classroom here is an assignment method for reviewing and completing assignments before the material is discussed in the classroom through the lecturer web or textbooks that have been provided.

The material that has been taught in this study were (1) the first cycle was about the concept of evaluation of learning result, (2) the second cycle was about measuring learning result, (3) the third cycle about assessing learning result, (4) the fourth cycle about learning result assessment tools, (5) the fifth cycle was about compiling a test of learning result in the field of geography, and (6) the sixth cycle about developing attitude measurement tools. The percentage of implementation of learning activities in the first cycle was $65 \%$, the second was $69 \%$, the third was $74 \%$, the fourth was $80 \%$, the fifth was $86 \%$, and the sixth was $90 \%$. Based on the conceptual understanding analysis results, students in studying the material in the evaluation course of geography study starting from cycle I to VI experienced a very significant improvement. The average result of conceptual understanding in the sixth cycle belongs to the high result understanding of concepts are in the score of 91 . Comprehension is a reconstruction of meanings and relationships and it is not just an assimilation of previously owned knowledge. "Providing learning experiences in the classroom effectively plays an important role in helping students' understanding of concepts" [20].

Student communication skills are assessed based on presentation activities. Based on the results of data exposure and research findings, it can be seen that the class' average result for communication skills in cycle one to cycle six has a very significant increase. Students of geography education Study Programs need communication skills to carry out the third internship in schools and perform in front of their students. This opinion is related to Son [21] statement, "communication skills can be trained, or prepared since the person concerned becomes a student teacher candidate." Therefore, lecturers need to train students' communication skills in every lesson in class. Thus students will be skilled at communicating well in communicating geographic thoughts to students when carrying out learning.

\section{CONCLUSION}

The flipped classroom-based presentation method through lesson study can increase students' conceptual understanding is in the score of 91 . This score is included in the criteria for high concept understanding.

The flipped classroom-based discussion method through lesson study, in general, can improve student communication skills. The increasing communication skills are in the score of 90. This result is included in the criteria for high communication skills.

\section{ACKNOWLEDGMENTS}

Thank you for the Lesson Study team for Geography Education Study Program and Belmawa for providing Lesson Study grants at FIP Universitas PGRI Kanjuruhan Malang.

\section{REFERENCES}

[1] S. Suwardjono, "Belajar Mengajar di Perguruan Tinggi; Redefinisi Makna Kuliah," Jurnal akuntansi dan manajemen STIE YKPN Yogyakarta, 2005.

[2] S.W. Abdul Latif, R. Matzin, R. Jawawi, M.A. Mahadi, J.H. Jaidin, L Mundia and M. Shahrill, "Implementing the Flipped Classroom Model in the Teaching of History," Journal of Education and Learning, vol. 11, no. 4, pp. 373-380, 2017.

[3] M.Y. Abdullah, S. Husin and I. Kamboja, "Implementation of Flipped Classroom Model and Its Effectiveness on English Speaking Performance," International Journal of Emerging Technologies in Learning (iJET), vol. 14, no. 9, pp. 130-147, 2019.

[4] S.M.J. Chua and F. Lateef, "The flipped classroom: Viewpoints in Asian universities," Education in Medicine Journal, vol. 6, no. 4, pp. 20-26, 2014. 
[5] C.P. Dwyer, M.J. Hogan and I. Stewart, "An Integrated Critical Thinking Framework for the 21st Century," Thinking Skills and Creativity, vol. 12, pp. 43-52, 2014.

[6] C.K. Lo and K.F. Hew, "A critical review of flipped classroom challenges in K-12 education: possible solutions and recommendations for future research," Research and Practice in Technology Enhanced Learning, vol. 12, no. 4, pp. 1-22, 2017.

[7] L.W. Johnson and J.D. Renner, Effect of the flipped classroom model on a secondary computer applications course: Student and teacher perceptions, questions and student achievement (Unpublished doctoral dissertation). University of Louisville, Louisville, KY, 2012.

[8] S.N.N.P. Manjanai and M. Shahrill, "Introducing the flipped classroom strategy in the learning of year nine factorization," International Journal of Interdisciplinary Educational Studies, vol. 11, no. 4, pp. 35-55, 2016.

[9] J.A. Arnott and S.L. Planey, "Flipped classroom approaches lead to no improvement in learning outcomes or student perceptions," The FASEB Journal, vol. 31, no. 1 Supplement, pp. 751-814, 2017.

[10] V. Aidinopoulou and D.G. Sampson, "An action research study from implementing the flipped classroom model in primary school history teaching and learning," Journal of Educational Technology \& Society, vol. 20, no. 1, pp. 237-247, 2017.

[11] I.W. Redhana, "Mengembangkan Keterampilan Abad Ke 21 dalam Pembelajaran Kimia [Developing 21st Century Skills in Chemistry Learning]," Jurnal Inovasi Pendidikan Kimia, vol. 13, no. 1, pp. 22392253, 2019 .

[12] A.D. Mazur, B. Brown and M. Jacobsen, "Learning designs using flipped classroom instruction," Canadian Journal of Learning and Technology, vol. 41, no. 2, pp. 1-26, 2015.
[13] N. Nawi, R. Jawawi, R. Matzin, J.H. Jaidin, M. Shahrill and L. Mundia," To flip or not to flip: The challenges and benefits of using flipped classroom in geography lessons in Brunei Darussalam," Review of European Studies, vol. 7, no. 12, pp. 133-145, 2015.

[14] A. Majid, Strategi Pembelajaran. Bandung: Remaja Rosdakarya, 2013.

[15] N. Somantri, Metode Presentasi dengan Ms Power Point untuk Mengembangkan Kemampuan Writing dan Speaking [Online]. Retrieved from: http://re-searchengines.com/0305somantri2.html, [Accessed on 15 December 2015]

[16] N. Purwanto, Prinsip-prinsip Evaluasi dan Teknik Evaluasi Pengajaran. Bandung: PT Remaja Rosda Karya, 2008.

[17] H. Ulya, Hubungan antara Kemampuan Berkomunikasi dengan Hasil Belajar Siswa melalui Pembelajaran Kooperatif Tipe Jigsaw. Skripsi Tidak Diterbitkan. Jakarta: UIN Syarif Hidayatullah Jakarta, 2011.

[18] F. Haithcock, A Guide to Implementing Lesson Study for District and School Leadership Teams in Differentiated Accountability Schools. Florida Department of Education, 2010.

[19] I. Syamsuri and I. Ibrohim, Lesson Study (Studi Pembelajaran). Malang: UM Press, 2007.

[20] D.C. Setiawan, Pengaruh Strategi Reciprocal Teaching Dipadu Pemberdayaan Berpikir Melalui Pertanyaan (PBMP) terhadap Kemampuan Metakognitif, Berpikir Kritis, dan Pemahaman Konsep Biologi Siswa SMAI Al Ma'arif Singosari Malang. Tesis Tidak Diterbitkan. Malang: PPs UM, 2013.

[21] A.L. Son, "Pentingnya Kemampuan Komunikasi Matematika Bagi Mahasiswa Calon Guru Matematika," Jurnal Gema Wiralodra, vol. 7, no. 1 , pp. 1-8, 2015 . 